\title{
Analysis on The Effect of Groyne Type Impermeable Placement on Sediment Distribution in Lariang River Bend
}

\author{
Wahyu Prasetyo ${ }^{1}$, Pitojo Tri Juwono ${ }^{2}$, Dian Sisinggih ${ }^{2}$ \\ ${ }^{1}$ Water Resources Engineer PT. Mulya Sakti Wijaya, Makassar, 90133 Indonesia \\ ${ }^{2}$ Water Resources Engineering Departement, Brawijaya Universitas, Malang, 65145 \\ Indonesia \\ gundol_88@yahoo.com \\ Received 01-12-2020; accepted 18-01-2021
}

\begin{abstract}
Sedimentation and erosion caused by differences in discharge is a problem that often occurs at river bends. One of the functions of placing the groyne is to reduce the river flow velocity along the riverbank, accelerate sedimentation, and ensure the embankment or river bank's safety against scouring. This study aimed to determine the distribution of current velocity, distribution of riverbed shear stress, and sediment distribution to the effect of groyne placement. There are 7 (seven) simulation models used to get the most effective groyne placement. From the model simulation results by adding a groyne building on the river's outer bend for the simulation model scenario 2 to scenario 7, the largest sedimentation production is in scenario 3, namely the height of riverbed sediment deposits 230 hours of $1.094 \mathrm{~m}$. Furthermore, the groyne building's effective placement is determined based on a maximum change in the riverbed scenario. In scenario 3, the placement and dimensions of the groyne length of $17.5 \mathrm{~m}$; distance between groyne $24.4 \mathrm{~m}$; the groyne is inclined upstream in the direction of flow $10^{\circ}$.
\end{abstract}

Keywords: erosion, groyne, river bends, sedimentation

\section{Introduction}

The river is the accumulation of water flowing to a lower place. Water that is on the plain's surface, whether it comes from rainwater, springs, or glacial fluids, will flow through a channel to a lower place. At first, the channel through which it was passed was narrow and short. Naturally, this water flow erodes the areas in which it passes. As a result, this channel was getting more comprehensive and more extended, and there was what was called a river.

As a result of this water flow, it will cause impacts in erosion, transportation, and sedimentation. These three activities depend on the watershed slope, river water volume, and water flow velocity [12]. The greater the slope of the river flow, the greater the erosion and transportation activities. Otherwise, the accumulation will be more intensive in bare areas, where the flow slowly so that water has the opportunity to settle the material it carries. This change occurs naturally due to the many treatments that

Cite this as: Prasetyo, W., Juwono, P. T., \& Sisinggih, D. (2021). Analysis on The Effect of Groyne Type Impermeable Placement to Sediment Distribution in Lariang River Bend. Civil and Environmental Science Journal (Civense), 4(1), 43-65. doi: https://doi.org/10.21776/ub.civense.2021.00401.5 
exist along the river, such as dams, reservoirs, bridges, and inevitable natural conditions such as bends in rivers [3].

Bends in rivers are a particular phenomenon to study because scouring and deposition often occur at river bends. In severe situations, large volumes of landslides can occur on river banks, which can cause damage to existing infrastructure. The cliff slide process occurs due to the continuous scouring process at the bottom of the channel. The scouring pattern that happens is very much influenced by discharge, riverbed slope, and time. The longer the water runoff occurs, and the greater the flow rate, the deeper and more prolonged the scouring occurs $[8,9,13]$.

In rivers where the current velocity is high, it causes erosion, both on the bank and the riverbed. Therefore a protective building is needed. Cliff protection buildings can be in the form of lining, walls, sheet piles, gabions, groyne, and others. The groyne is one of the protective structures installed across the riverbank, aiming to slow down the flow's speed around the groyne. The erosion process will be avoided and even sedimentation will occur. Thus, on the cliffs, where the erosion process was initially occurring, it becomes protected and even sedimentation occurs due to the groyne's presence [11].

Several studies related to the groyne structure have been carried out [11] and state that one of the most effective scours countermeasures is using a groyne structure to protect the river bank from highspeed currents [6].

The purpose of this study was to determine the velocity distribution with the groyne building on the river bend; to determine the primary shear stress and the distribution of sedimentation in the presence of a groyne building on a river bend; analyzing the effect of the effective placement of the groyne to minimize erosion at river bends.

\section{Material and Methods}

\section{a. Material}

Administratively, the Lariang River is included in the Lariang Watershed. It is located in 3 (three) provinces, namely Central Sulawesi, West Sulawesi and South Sulawesi Provinces, which consists of 5 (five) districts, namely North Mamuju Regency, Donggala Regency, Sigi Regency, Poso Regency, and North Luwu Regency. The Lariang Watershed is located between $1^{\circ} 11$ ' 15 "- $2^{\circ} 22^{\prime \prime} 48$ " South Latitude and $119^{\circ} 17 " 15$ "- $120^{\circ} 30^{\prime \prime} 7$ " East Longitude. The research location is located at $1^{\circ} 26$ '33 " South Latitude and $119^{\circ} 21^{\prime \prime} 36^{\prime \prime}$ East Longitude.

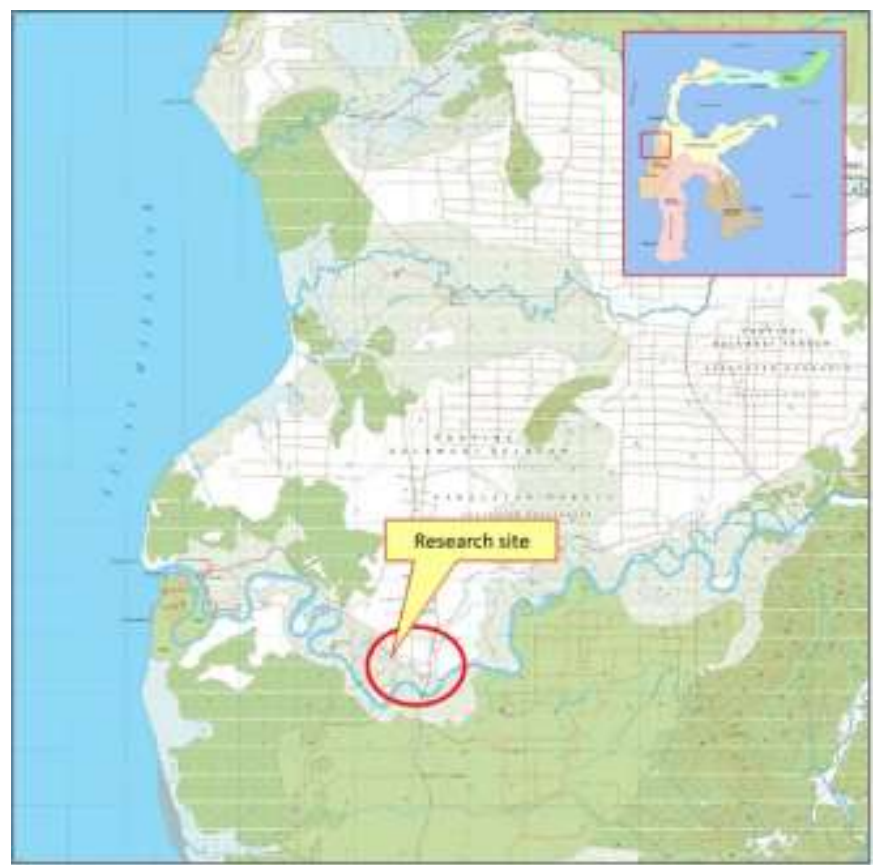

Figure 1. Research Site 
The Lariang Watershed, covering $7264.97 \mathrm{~km}^{2}$, is one part of the Palu Lariang River Basin, consisting of 52 watersheds. The Lariang River has an upstream in Poso Regency, Central Sulawesi Province and North Luwu Regency, South Sulawesi Province, and empties into the Makassar Strait.

The downstream area of the Lariang Watershed, which is administratively included in the North Mamuju Regency, is the area that has been the worst affected by the destructive force of the Lariang River. The main problems in the downstream area of the Lariang watershed are the scouring of cliffs river at the river's outer bend and inundation due to the Lariang River's flooding.

The data used in the study are as follows:

1. River geometry data measured in 2017.

2. Designed flood discharge data calculated from the Sulawesi River Basin III in 2017.

3. Data for sediment gradient analysis baseline (bedload) from the Sulawesi III River Basin in 2017.

4. Data elevation of former flood historical water levels measured in 2014.

\section{b. Methods}

The method used in the assessment of this study is a 2-dimensional numerical model simulation using the Resources Management Associates-2 (RMA2) and SED2D models as follows:

- RMA2 Model

RMA2 model is a two-dimensional finite element numerical model used to solve hydrodynamic problems at location water, assuming an average depth. RMA2 works in range the sub-flow critical. RMA2 calculates water level elevation and horizontal flow velocity at each node in the model domain.

The Reynolds form in the equation Navier-Stokes used to calculate the turbulent flow. Friction is calculated using the Manning equation and the eddy viscosity coefficient is used to define turbulent characteristics. RMA2 solves both lasting and dynamic problems.

The numerical model RMA2 solves the equation for the conservation of mass and momentum of water integrated into the mean depth (depth-averaged) in two horizontal dimensions. The vertical directional acceleration is negligible, so the velocity vector is excellent and the direction is the same along the water column. The average depth flow velocity u used by RMA2 is stated in the following equation [4]:

$$
U=\frac{1}{h} \int_{0}^{h} u(z) d z
$$

with :

$$
\begin{aligned}
\mathrm{U}= & \text { flow velocity mean depth (in } \mathrm{x} \text { direction) } \\
\mathrm{h}= & \text { elemental water depth } \\
\mathrm{u}(\mathrm{z})= & \text { flow velocity as a function of vertical direction } \\
\mathrm{z}= & \text { vertical coordinates } \\
& \text { the form of the equation for RMA2 that has been solved is [4]: }
\end{aligned}
$$

$$
h \frac{\partial u}{\partial t}+h u \frac{\partial u}{\partial x}+h v \frac{\partial u}{\partial y}-\frac{h}{\rho}\left[E_{x x} \frac{\partial^{2} u}{\partial x^{2}}+E_{x y} \frac{\partial^{2} u}{\partial y^{2}}\right]+g h\left[\frac{\partial a}{\partial x}+\frac{\partial h}{\partial x}\right]+\frac{g u n^{2}}{\left(1,486 h^{\frac{1}{6}}\right)^{2}}\left(u^{2}+v^{2}\right)^{\frac{1}{2}}-\zeta V_{a}^{2} \cos \psi-
$$

$2 h v \omega \sin \varphi=0$

$$
h \frac{\partial v}{\partial t}+h u \frac{\partial v}{\partial x}+h v \frac{\partial v}{\partial y}-\frac{h}{\rho}\left[E_{y x} \frac{\partial^{2} v}{\partial x^{2}}+E_{y y} \frac{\partial^{2} v}{\partial y^{2}}\right]+g h\left[\frac{\partial a}{\partial y}+\frac{\partial h}{\partial y}\right]+\frac{g v n^{2}}{\left(1,486 h^{\frac{1}{6}}\right)^{2}}\left(u^{2}+v^{2}\right)^{\frac{1}{2}}-\zeta V_{a}^{2} \cos \psi-
$$

$2 \operatorname{hu\omega } \sin \varphi=0$

$\frac{\partial h}{\partial t}+h\left(\frac{\partial u}{\partial x}+\frac{\partial v}{\partial y}\right)+u \frac{\partial h}{\partial x}+v \frac{\partial h}{\partial y}=0$ 
where :

$\mathrm{h} \quad=$ water depth

$\mathrm{u}, \mathrm{v} \quad=$ velocity $\mathrm{x}$ and $\mathrm{y}$

$\mathrm{x}, \mathrm{y}, \mathrm{t}=$ Cartesian coordinates and time

$\rho \quad=$ density of liquid

$\mathrm{E}=$ Eddy viscosity coefficient

for $\mathrm{xx}=$ normal direction on $\mathrm{x}$ axis surface

for $y y=$ normal direction on $y$ axis surface

for $\mathrm{xy}$ and $\mathrm{yx}=$ shear direction on each surface

$\mathrm{g}=$ acceleration due to gravity

a = elevation of bottom

$\mathrm{n} \quad=$ Manning's roughness n-value

$1.486=$ conversion from SI (metric) to non-SI units

$\zeta=$ empirical wind shear coefficient

$\mathrm{Va} \quad=$ wind speed

$\Psi \quad=$ wind direction

$\omega=$ rate of earth's angular rotation

$\Phi \quad=$ local latitude

- SED2D Model

SED2D software analyzes two sediments: non-cohesive sediments (sand) and cohesive sediments (clay). This numerical model only examines one sufficient grain size of each run, which requires a separate run model for each sufficient grain size. The concentration of sediment suspended calculated by using equation convection-diffusion equipped with a bed source term [7]:

$\frac{\partial C}{\partial t}+u \frac{\partial C}{\partial x}+v \frac{\partial C}{\partial y}=\frac{\partial}{\partial x}\left(D x \frac{\partial C}{\partial x}\right)+\frac{\partial}{\partial y}\left(\frac{\partial C}{\partial y}\right)+\alpha_{1} C+\alpha_{2}$

where:

$\mathrm{C}=$ concentration, $\mathrm{kg} / \mathrm{m}^{3}$

$\mathrm{t} \quad=$ time, sec

$\mathrm{u} \quad=$ flow velocity in $\mathrm{x}-$ direction, $\mathrm{m} / \mathrm{sec}$

$\mathrm{x} \quad=$ primary flow direction, $\mathrm{m}$

$\mathrm{v}=$ flow velocity in $\mathrm{y}-$ direction, $\mathrm{m} / \mathrm{sec}$

$\mathrm{y} \quad=$ direction perpendicular to $\mathrm{x}, \mathrm{m}$

$\mathrm{D}_{\mathrm{x}} \quad=$ effective diffusion coefficient in $\mathrm{x}-$ direction, $\mathrm{m}^{2} / \mathrm{sec}$

$\mathrm{D}_{\mathrm{y}} \quad=$ effective diffusion coefficient in $\mathrm{y}$ - direction, $\mathrm{m}^{2} / \mathrm{sec}$

$\alpha_{1} \quad=$ a coefficient for the source term, $1 / \mathrm{sec}$

$\alpha_{2}=$ the equilibrium concentration portion of the source term, $\mathrm{kg} / \mathrm{m}^{3} / \mathrm{sec}=-\alpha_{1} \mathrm{C}_{\mathrm{eq}}$

Ackers and White's formulation is used to calculate the transport potential $\left(\mathrm{C}_{\mathrm{eq}}\right)$ sedimentary material about sand's size [1, 5]. Meanwhile, the characteristic timing (tc) is somewhat subjective. Because tc is the time required for the concentration in the flow field to change from $\mathrm{C}$ to $\mathrm{C}_{\text {eq. }}$. In the case of deposition, the characteristic time is associated with falling velocity, and the following equation is used [7]:

where:

$$
t_{c}=C_{d} \frac{H}{V_{s}} \text { or tc }=\mathrm{DT}
$$

$\mathrm{t}_{\mathrm{c}}=$ characteristic time

$\mathrm{C}_{\mathrm{d}}=$ coefficient for deposition

$\mathrm{D}=$ flow depth

$\mathrm{V}_{\mathrm{s}}=$ fall velocity of a sediment particle 
$\mathrm{DT}=$ computation time interval

Meanwhile, to calculate the river bed shear stress using the formula [7]:

$$
\tau_{\mathrm{b}}=\rho\left(\mathrm{u}^{*}\right)^{2}
$$

where:

$$
\begin{array}{ll}
\rho & =\text { water density } \\
\mathrm{u}^{*} & =\text { shear velocity }
\end{array}
$$

For $\mathrm{u}^{*}$, use the Bijker equation to calculate the total shear stress due to waves and currents. The equation is as follows [7]:

$u^{*}=\sqrt{\frac{1}{2} f_{c} \overline{\mathrm{U}}^{2}+\frac{1}{4} f_{w} u_{o m}^{2}}$

Bed Source quantity [2]:

$$
\mathrm{S}=\alpha_{1} \mathrm{C}_{+} \alpha_{2}
$$

The quantity of bed source is divided into two formulations, namely:

a. For Sand

The bed source term's shape is $\mathrm{S}=\alpha 1^{\mathrm{C}}+\alpha 2$, used for analysis deposition and erosion at the bottom. The method of calculating the alpha coefficient depends on the type of material. Sediment transport at the bottom is controlled by the potential for flow transport and the availability of material at the base, so that the form of the equation bed source term becomes [7]:

$$
S=\frac{C_{e q}-C}{t_{c}}
$$

with :

$\mathrm{S} \quad=$ source term

$\mathrm{C}_{\mathrm{eq}} \quad=$ equilibrium concentration (transport potential)

$\mathrm{C}=$ sediment concentration in the water column

$\mathrm{t}_{\mathrm{c}} \quad=$ characteristic time for effecting the transition

For time characteristics using the case, it is deposition formulated as follows [7]:

$\mathrm{T}_{\mathrm{c}}=$ greater form $C d \frac{D}{V S}$ or DT

with :

$\mathrm{t}_{\mathrm{c}} \quad=$ characteristic time

$\mathrm{C}_{\mathrm{d}} \quad=$ coefficient for deposition

$\mathrm{D}=$ flow depth

$\mathrm{V}_{\mathrm{s}} \quad$ = fall velocity of a sediment particle

DT = computation time interval

b. For Clay [7]

$S=-\frac{V_{s}}{D} C\left(1-\frac{\tau}{\tau_{d}}\right)$ for $\mathrm{C}<C_{c}, \tau<\tau_{d}$

$S=-\frac{V_{k}}{D} C^{7 / 3}\left(1-\frac{\tau}{\tau_{d}}\right)$ for $C>C_{c}, \tau>\tau_{d}$

with:

$\tau \quad=$ bed shear stress

$\tau_{\mathrm{d}}=$ critical shear stress for deposition

$\mathrm{C}_{\mathrm{c}}=$ critical concentration $=300 \mathrm{mg} / \mathrm{l}$ 
- Groyne Formation

a. Normal Groyne (perpendicular)

The normal groyne is built to narrow the part of the river. The river has become too wide and on the convex side of the river bend.

b. Upstream inclined Groyne

On permeable inclined upstream, scouring will occur at the groyne's front end while sedimentation generally occurs near river cliffs and the flow will lead to the middle of the river. This groove is very useful for protecting the river cliffs.

c. Downstream inclined Groyne

On permeable groyne that leans downstream, scour at the front end of the groyne tends to decrease and hence deposition may occur downstream of the groyne.

Table 1. Flow Direction and Axis Angle Groyne [10]

\begin{tabular}{cc}
\hline Location of Groyne in River & Flow Direction and Axis Angle Groyne \\
\hline Perpendicular & $10^{\circ}-15^{\circ}$ \\
\hline Outside & $5^{\circ}-15^{\circ}$ \\
\hline Inside Bend & $0^{\circ}-10^{\circ}$ \\
\hline
\end{tabular}

In this simulation, the data required as the model input is secondary data obtained from BWS Sulawesi III and primary data taken directly at the study location. These data are simulated into a model to determine velocity, shear stress and sediment distribution using 7 (seven) scenarios for placing groyne.

The stages of the method used in this study are as follows:

1. Input river geometry data is in the form of data contour and cross-section with 7 (seven) scenarios for placing the groyne.

2. Input the boundary condition in the form of discharge data per unit time for the RMA2 simulation.

3. Simulation of the RMA2 model aims to determine the water level and velocity of the flow direction, which will be used as model validation through the test MRE (Mean Relative Error) [5] the following calculations:

$M R E=\frac{h_{c}-h_{0}}{\mathrm{~h}_{0}} X 100 \%$

where :

$\mathrm{hc}=$ water level elevation model

ho $=$ history flood elevation

4. Calibration, to make the model to be used close to the actual condition.

5. Simulation of the SED2D Model, this model's input is in sediment grains gradation data and data suspended load.

Table 2. Input value of SED2D Model

\begin{tabular}{cccc}
\hline No & Parameter & Unit & Value \\
\hline 1 & Diffusion Coeffisient & $\mathrm{m}^{2} / \mathrm{sec}$ & 100 \\
\hline 2 & Initial Concentration & $\mathrm{kg} / \mathrm{m}^{3}$ & 0.20 \\
\hline 3 & Settling velocity & $\mathrm{m} / \mathrm{sec}$ & 0.9 \\
\hline 4 & Specific gravity & $\mathrm{kg} / \mathrm{m}^{3}$ & 2773 \\
\hline 5 & Grain shape factor & - & 0.67 \\
\hline 6 & $\begin{array}{c}\text { Characteristic deposition } \\
\text { length factor }\end{array}$ & ' $\mathrm{m}$ & 1.00 \\
\hline 7 & Thickness & ' $\mathrm{m}$ & 1.00 \\
\hline 8 & Sand grain roughness & - & 1.00 \\
\hline 9 & Sand grain size & $\mathrm{mm}$ & 9.5 \\
\hline \multicolumn{4}{c}{} \\
\hline
\end{tabular}


6. Comparative analysis of simulation results aims to determine the more effective crib placement in reducing river bank scour

\section{Result and Discussion}

\section{a. MRE Test/Calibration}

Before proceeding to the modelling stage, it is necessary to validate the model against the initial simulation to ensure that the model can represent field conditions. Validation is carried out on the modelling results to determine the model's suitability to the actual field conditions. In this case, it is done by comparing the modelling results' water level with the flood events' historical water level elevation data.

Based on the MRE test, the model's accuracy level will be known to the field's actual conditions. The test results that are close to the relative error value, which is assumed to be $\leq 10 \%$, show that the results are appropriate, so there is no need to calibrate the model (Table 3). The test results show that the MRE of the RMA2 model was calibrated using a manning number of 0.03 and a turbulent exchange coefficient (eddy viscosity) of $500 \mathrm{~m}^{2} / \mathrm{sec}$. The model results approach the actual conditions.

Tabel 3. Result of MRE Test

\begin{tabular}{c|c|c|c}
\hline \multirow{2}{*}{$\begin{array}{c}\text { Return } \\
\text { Flood } \\
\begin{array}{c}\text { Discharge } \\
\text { (years) }\end{array}\end{array}$} & $\begin{array}{c}|c| \\
\text { Wesult } \\
\text { Model } \\
\text { Test }\end{array}$ & $\begin{array}{c}\text { Flood } \\
\text { History }\end{array}$ & $\begin{array}{c}\text { Result of } \\
\text { MRE } \\
\text { Test }(\%)\end{array}$ \\
\hline 1.25 & 18.23 & 17.82 & 2.30 \\
\hline 20.00 & 18.81 & 19.33 & 2.69 \\
\hline
\end{tabular}

\section{b. Scenario Modelling 1}

- Model Simulation RMA2

RMA2 Model Simulation Scenario 1 is carried out when the river is in a condition with no groyne. The RMA2 Model Simulation is conducted to obtain the distribution of river flow velocity at the research location (Figure 2). Figure 2 shows that the arrows are the direction of the flow and the colour gradations are dominated by green and blue. The green colour represents the current velocity value of $1.9 \mathrm{~m} / \mathrm{sec}$ and the blue colour represents the current velocity value of $2.5 \mathrm{~m} / \mathrm{sec}$. So that in existing conditions, the distribution of flow velocity at the research location ranges from $1.1 \mathrm{~m} / \mathrm{sec}-2.5 \mathrm{~m} / \mathrm{sec}$, evenly distributed on the left, centre and right of the river.

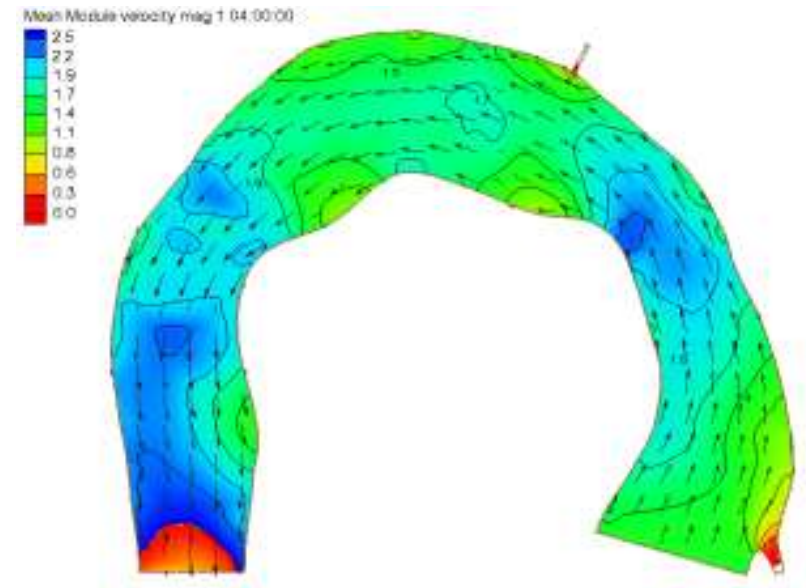

Figure 2. RMA Simulation Results $\left(\mathrm{Q}_{20}\right)$ Scenario 1

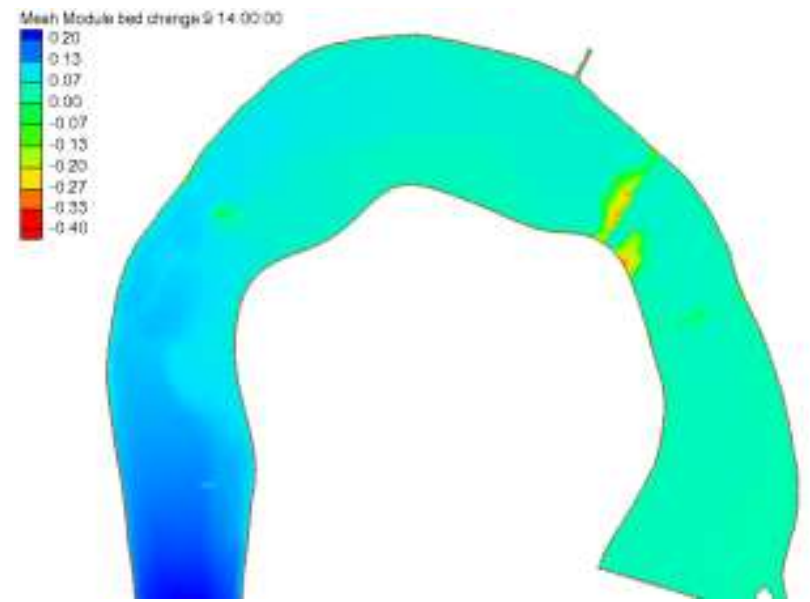

Figure 3. SED2D Simulation Results $\left(\mathrm{Q}_{20}\right)$ Scenario 1 
- Model Simulation SED2D

This model aims to determine the shear stress and distribution of riverbed sediments with river conditions without buildings by looking at the effect of the discharge of $\mathrm{Q}_{20}$ (Figure 3).

Figure 3 shows that the colour gradation is dominated by blue. There are also yellow and green colours. The yellow colour means that there has been a change in the riverbed of $-0.20 \mathrm{~m}$, the green colour means that there is no change in the river bed, and the blue colour means that there has been a change in the riverbed of $0.20 \mathrm{~m}$. The condition of the existing river is a change in the river bed due to the $\mathrm{Q}_{20}$ flood discharge of $0.07 \mathrm{~m}$ to $0.20 \mathrm{~m}$, spread evenly on the left, centre and right of the river.
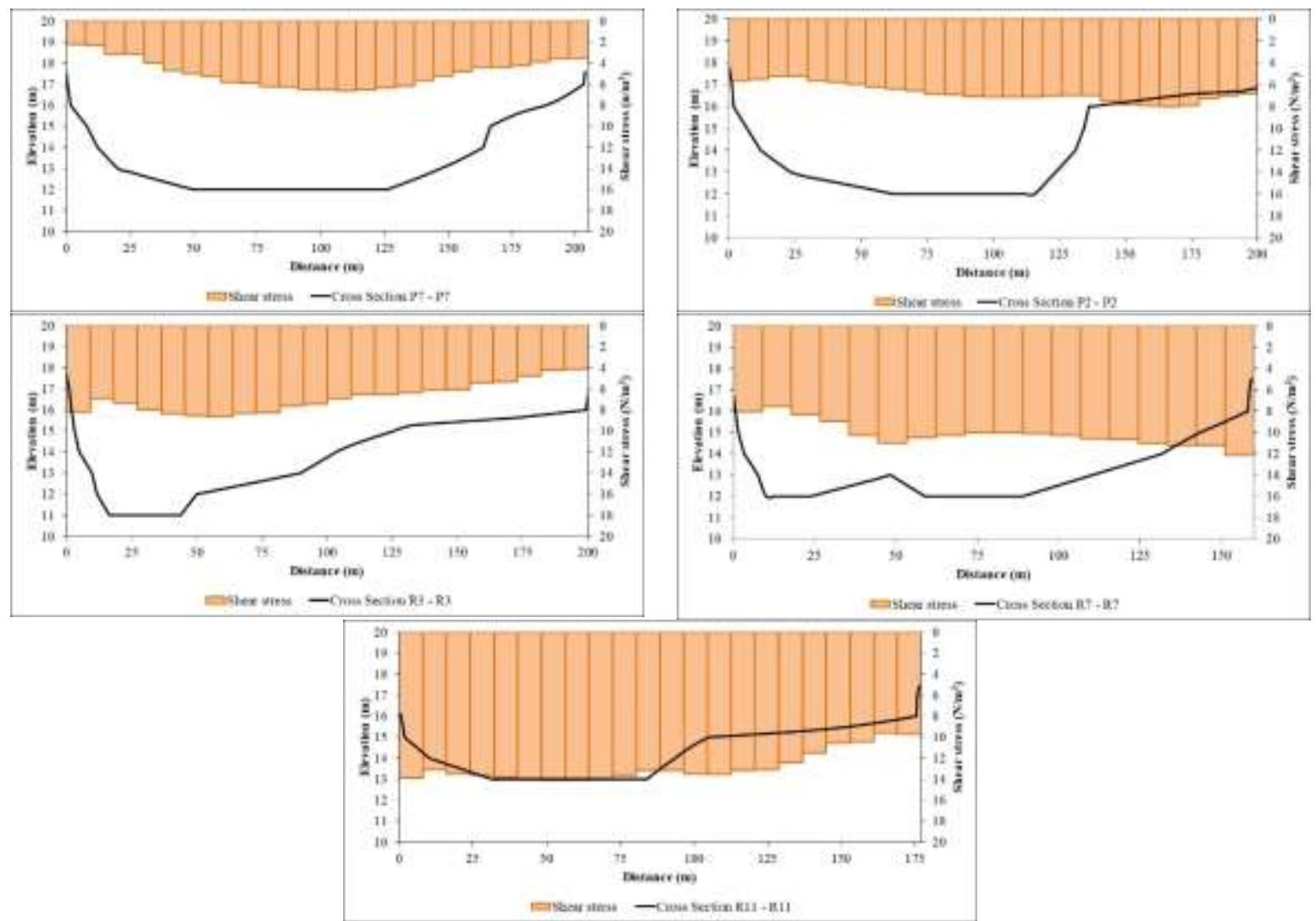

Figure 4. Distribution of Shear Stress (T) Riverbed Scenario $1\left(\mathrm{Q}_{20}\right)$

Figure 4 shows the distribution of riverbed shear stresses the effect of flood discharge $20\left(\mathrm{Q}_{20}\right)$ on the river's cross section. Figure 4 shows that the distribution of riverbed shear stress is evenly distributed on the left, centre and right of the river.

\section{c. Scenario Modelling 2}

\section{- Model Simulation RMA2}

The 2-step scenario modelling is the same as the modelling scenario 1 (existing), but in this scenario two, we will place 32 groynes on the outer bend of the river, with the dimensions of the groyne: length of $17.5 \mathrm{~m}$; groyne perpendicular to flow; distance between groyne $24.4 \mathrm{~m}$.

Figure 5 shows that the arrows are the direction of the flow and the colour gradations consisting of red, yellow, green, and blue. The red colour represents the current velocity value of $0.0 \mathrm{~m} / \mathrm{sec}$. The yellow colour represents the current velocity value of $0.98 \mathrm{~m} / \mathrm{sec}$. The green colour represents the current velocity value of $1.97 \mathrm{~m} / \mathrm{sec}$, and the blue colour represents the current velocity value of $2.95 \mathrm{~m} / \mathrm{sec}$. 
The red colour dominates the river's outer side (right bank), yellow to blue colours dominate the inside of the river (left bank) and the river's middle.

Placing the groyne building on the river's outer side (right bank) can reduce the river flow velocity. The low flow velocity allows sedimentation to occur on the river's outer side (right bank). The process of placing the groove as a river flow direction building can function following what was planned.

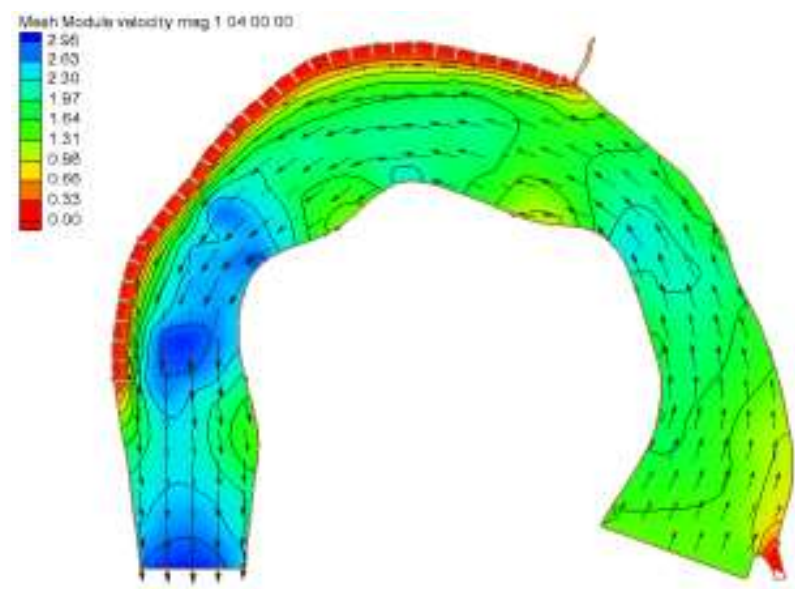

Figure 5. RMA Simulation Results $\left(\mathrm{Q}_{20}\right)$ Scenario 2

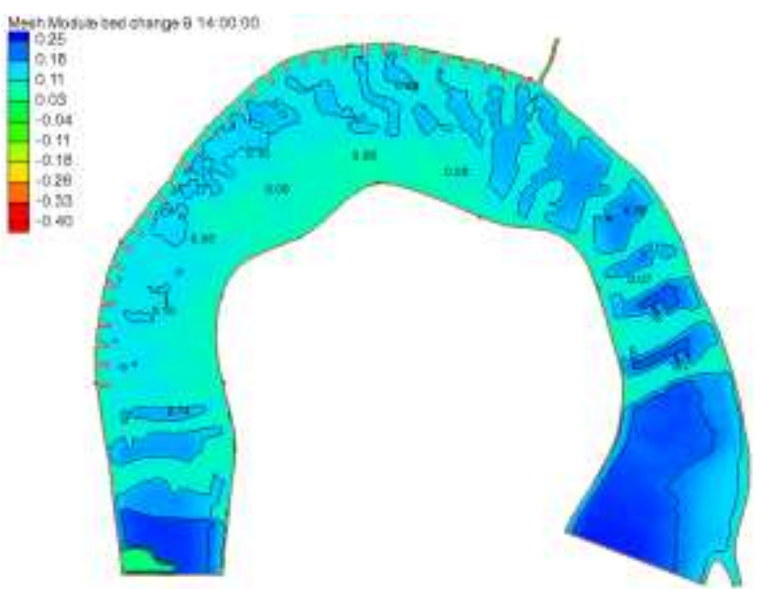

Figure 6. SED2D Simulation Results $\left(\mathrm{Q}_{20}\right)$ Scenario 2
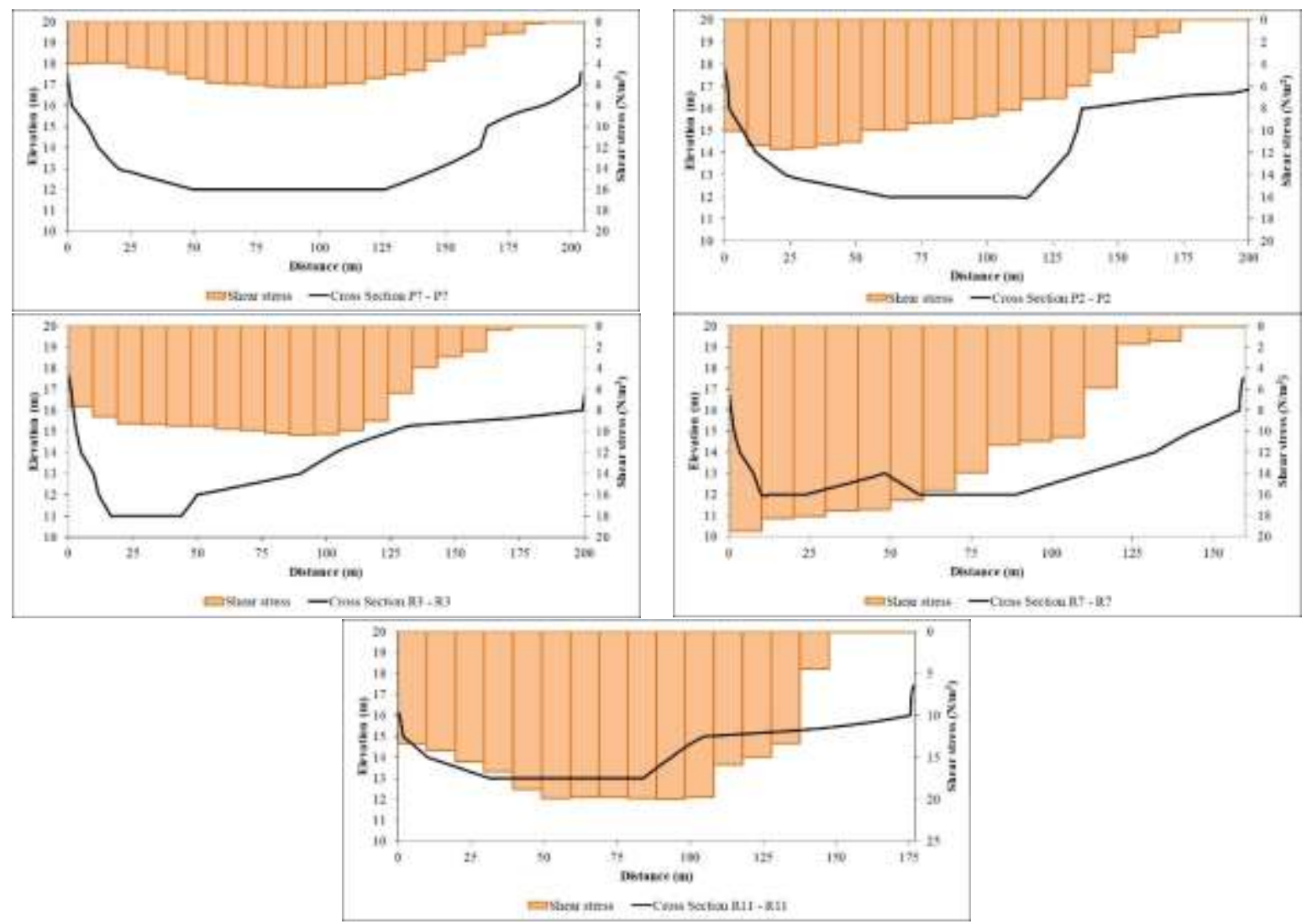

Figure 7. Distribution of Shear Stress (T) Riverbed Scenario $2\left(\mathrm{Q}_{20}\right)$ 


\section{- Model Simulation SED2D}

The SED2D model simulation aims to determine the distribution of sediment and river bed shear stress by adding 32 groyne. The groyne's dimensions: length $17.5 \mathrm{~m}$; groyne perpendicular to flow; distance between groyne $24.4 \mathrm{~m}$; due to the influence of $\mathrm{Q}_{20}$. From Figure 6, it can be seen that blue colours dominate the colour gradation. The blue colour means that there has been a change in the riverbed of $0.25 \mathrm{~m}$. In scenario 2, there is a change in the river bed due to the $\mathrm{Q}_{20}$ flood discharge of 0.03 $\mathrm{m}$ to $0.25 \mathrm{~m}$, spread evenly on the left, centre and right of the river.

The minimum river bed shear stress occurs on the river's right bank (outer river bend) and the maximum river bed shear stress occurs on the left bank of the river (inner river bend) (Figure 7). Low riverbed shear stress values allow sedimentation, while high riverbed shear stress values allow erosion. In this condition, there is a sedimentation process on the river's right bank (outer river bend) and an erosion process occurs on the left bank of the river (bend in the river).

\section{d. Scenario Modelling 3}

\section{- Model Simulation RMA2}

The 3-step scenario modelling the same as the modelling in scenario 2, it only changes the curb's direction towards the upstream direction of the flow by $10^{\circ}$ (Figure 8 ). Figure 8 shows that the arrows are the direction of the flow and the colour gradations consisting of red, yellow, green, and blue. The red colour represents the current velocity value of $0.0 \mathrm{~m} / \mathrm{sec}$. The yellow colour represents the current velocity value of $1.00 \mathrm{~m} / \mathrm{sec}$. The green colour represents the current velocity value of $2.00 \mathrm{~m} / \mathrm{sec}$, and the blue colour represents the current velocity value of $3.00 \mathrm{~m} / \mathrm{sec}$. The red colour dominates the river's outer side (right bank), yellow to blue colours dominate the inside of the river (left bank) and the river's middle. Placing the groyne building on the river's outer side (right bank) can reduce the river flow velocity to a low. The low flow velocity allows sedimentation to occur on the river's outer side (right bank). The process of placing the groove as a river flow direction building can function following what was planned.

\section{- Model Simulation SED2D}

The SED2D model simulation aims to determine the distribution of sediment and river bed shear stress by adding 32 groyne, with the groyne's dimensions: length of $17.5 \mathrm{~m}$; groyne inclined $10^{\circ}$ to upstream; distance between groyne $24.4 \mathrm{~m}$; due to the influence of $\mathrm{Q}_{20}$.

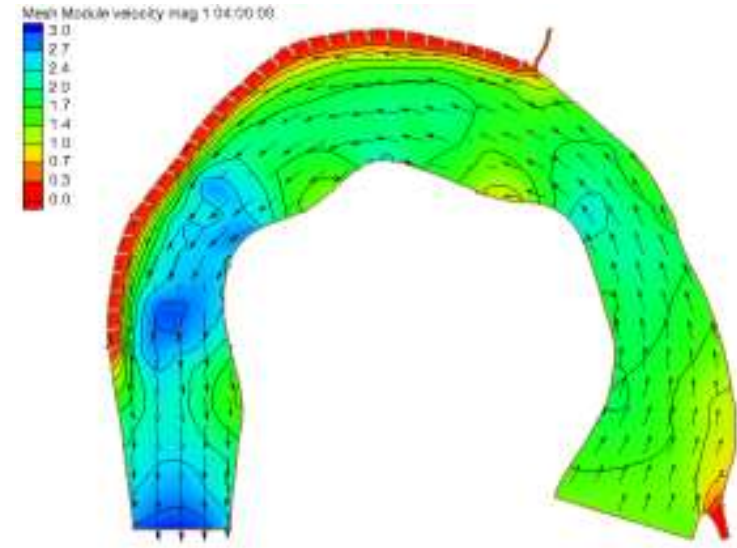

Figure 8. RMA Simulation Results $\left(\mathrm{Q}_{20}\right)$ Scenario 3

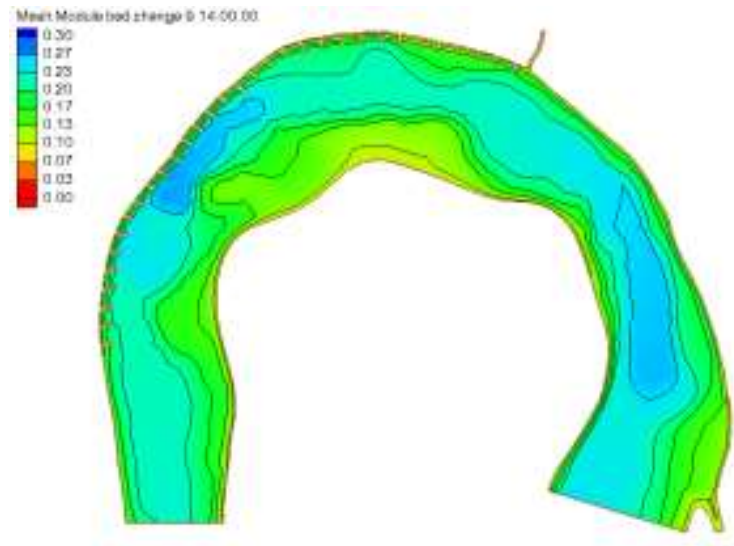

Figure 9. SED2D Simulation Results $\left(\mathrm{Q}_{20}\right)$ Scenario 3

Figure 9 show that the green and blue colours dominate the colour gradation. There is a change in the river bed in scenario three due to the $\mathrm{Q}_{20}$ flood discharge of $0.13 \mathrm{~m}$ to $0.27 \mathrm{~m}$, which is spread evenly on the left, centre and right of the river. 

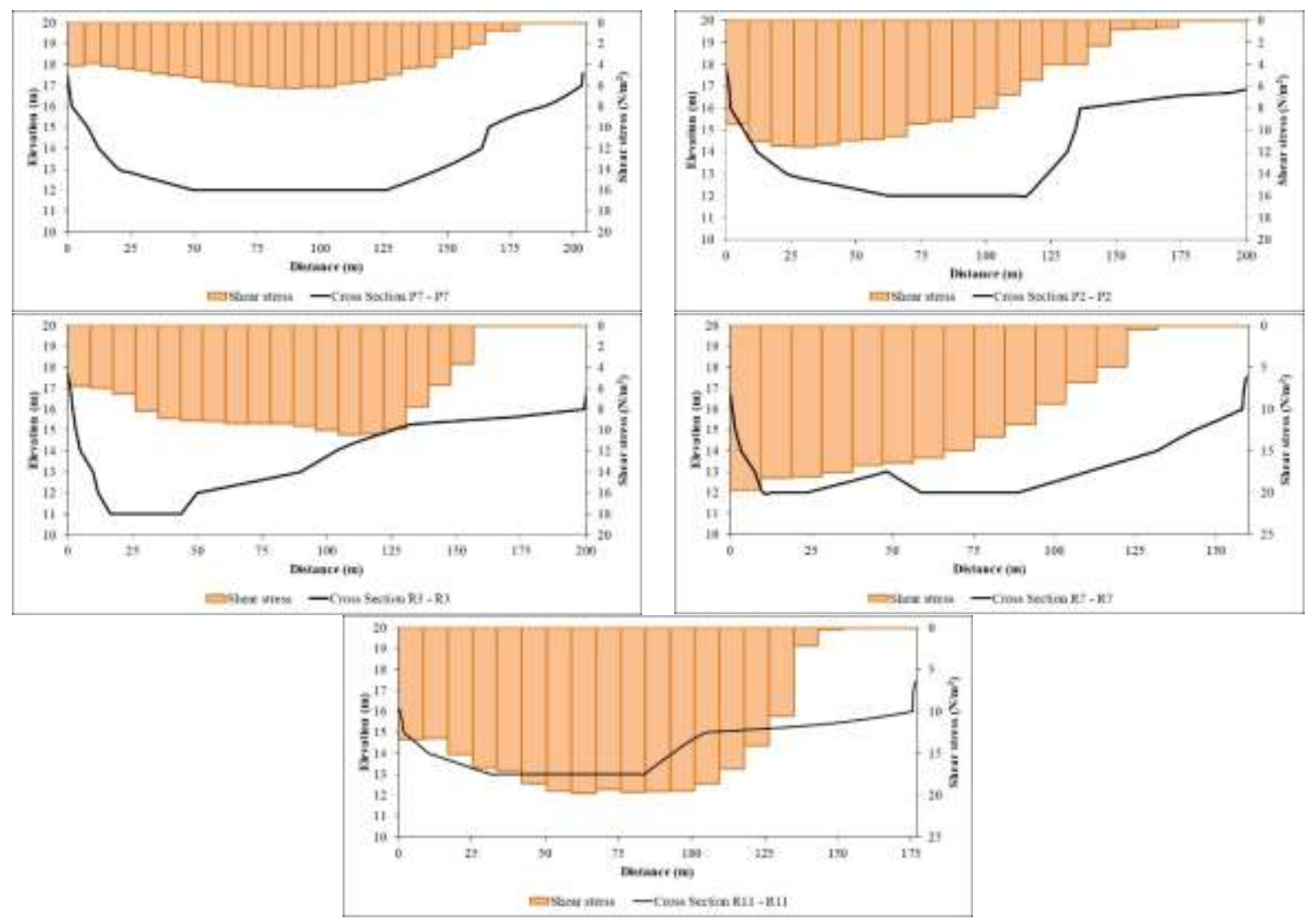

Figure 10. Distribution of Shear Stress (T) Riverbed Scenario $3\left(\mathrm{Q}_{20}\right)$

Figure 10 shows that the minimum river bed shear stress occurs on the river's right bank (outer river bend) and the maximum river bed shear stress occurs on the left bank of the river (inner river bend). Low riverbed shear stress values allow sedimentation. However, high riverbed shear stress values allow erosion. In this condition, there is a sedimentation process on the river's right bank (outer river bend) and an erosion process occurs on the left bank of the river (bend in the river).

\section{e. Scenario Modelling 4}

- Model Simulation RMA2

The 4-step scenario modelling the same as the modelling in scenario 2, it only changes the direction of the curb inclined towards the downstream direction of the flow by $10^{\circ}$ (Figure 11).

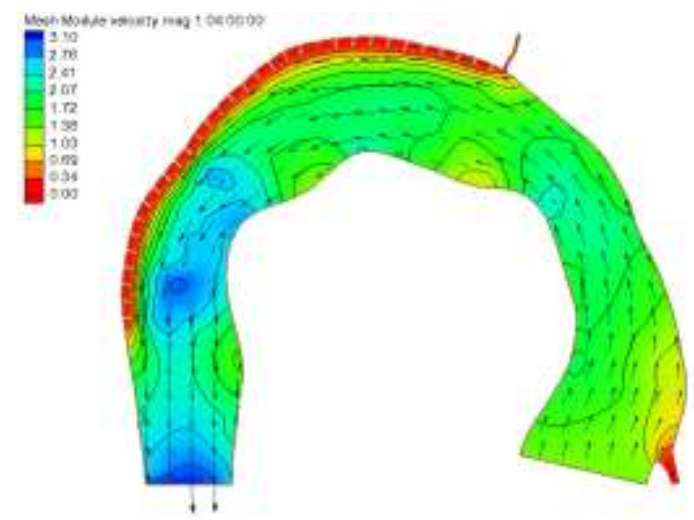

Figure 11. RMA Simulation Results $\left(\mathrm{Q}_{20}\right)$ Scenario 4

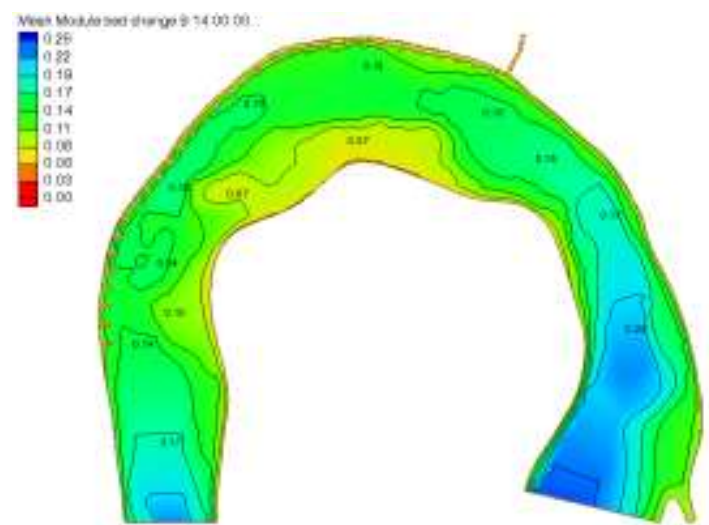

Figure 12. SED2D Simulation Results $\left(\mathrm{Q}_{20}\right)$ Scenario 4 
Figure 11 shows that the arrows are the direction of the flow and the colour gradations consisting of red, yellow, green, and blue. The red colour represents the current velocity value of $0.0 \mathrm{~m} / \mathrm{sec}$. The yellow colour represents the current velocity value of $1.03 \mathrm{~m} / \mathrm{sec}$.

The green colour represents the current velocity value of $2.07 \mathrm{~m} / \mathrm{sec}$, and the blue colour represents the current velocity value of $3.10 \mathrm{~m} / \mathrm{sec}$. The red colour dominates the river's outer side (right bank), yellow to blue colours dominate the inside of the river (left bank) and the river's middle.

Placing the groyne building on the river's outer side (right bank) can reduce the river flow velocity to a low. The low flow velocity allows sedimentation to occur on the river's outer side (right bank). The process of placing the groove as a river flow direction building can function following what was planned.

\section{- Model Simulation SED2D}

The SED2D model simulation aims to determine the distribution of sediment and river bed shear stress by adding 32 groynes. The groyne's dimensions: length of $17.5 \mathrm{~m}$; groyne inclined $10^{\circ}$ to the downstream; distance between groyne $24.4 \mathrm{~m}$; due to the influence of $\mathrm{Q}_{20}$.

From Figure 12, it can be seen that green and blue colours dominate the colour gradation. In scenario four, there is a change in the river bed due to the $\mathrm{Q}_{20}$ flood discharge of $0.08 \mathrm{~m}$ to $0.22 \mathrm{~m}$, spread evenly on the left, centre and right of the river.

Figure 13 shows that the minimum river bed shear stress occurs on the river's right bank (outer river bend) and the maximum river bed shear stress occurs on the left bank of the river (inner river bend). Low riverbed shear stress values allow sedimentation. However, high riverbed shear stress values allow erosion. In this condition, there is a sedimentation process on the river's right bank (outer river bend), and an erosion process occurs on the left bank of the river (bend in the river).
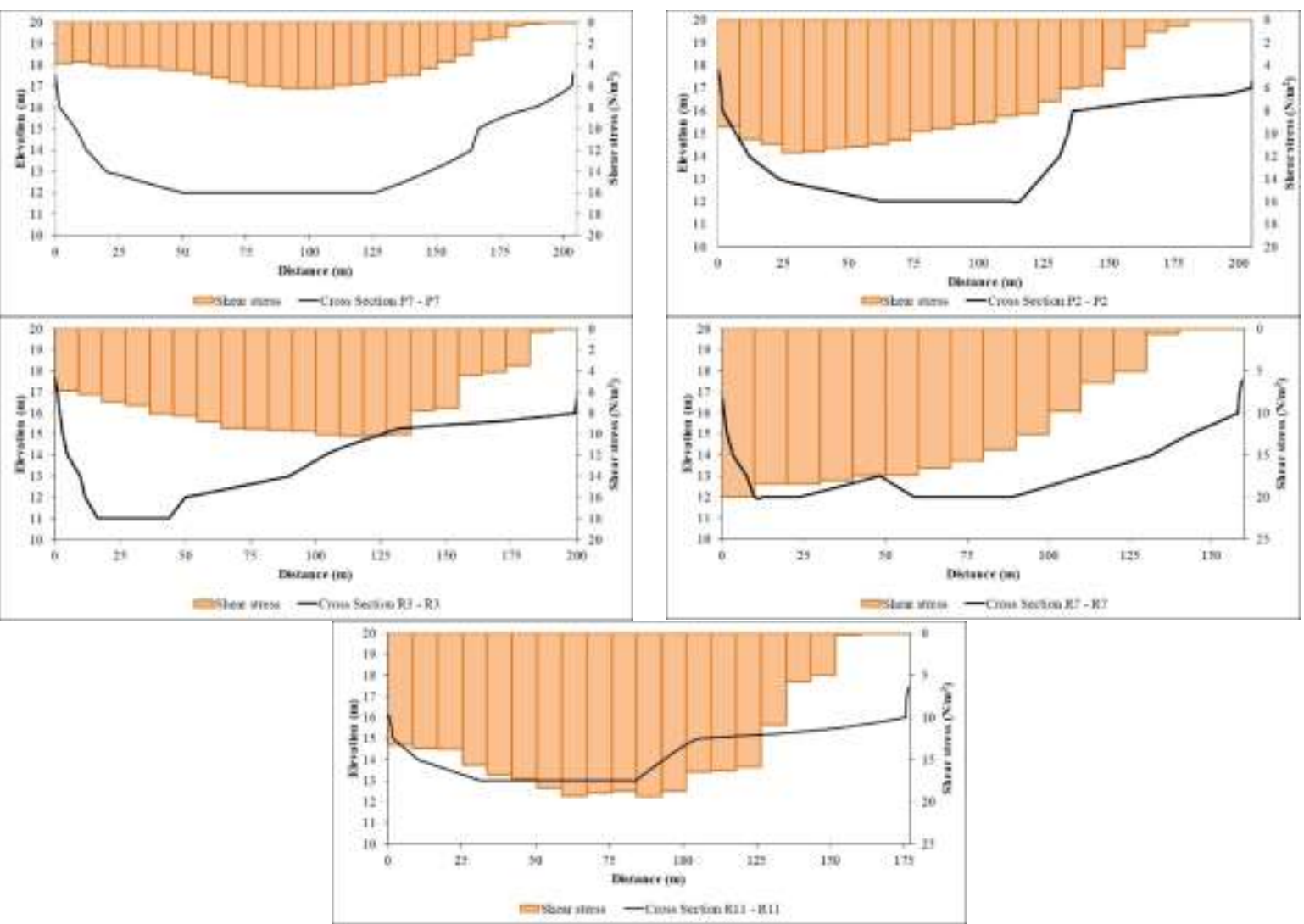

Figure 13. Distribution of Shear Stress (T) Riverbed Scenario $4\left(\mathrm{Q}_{20}\right)$ 


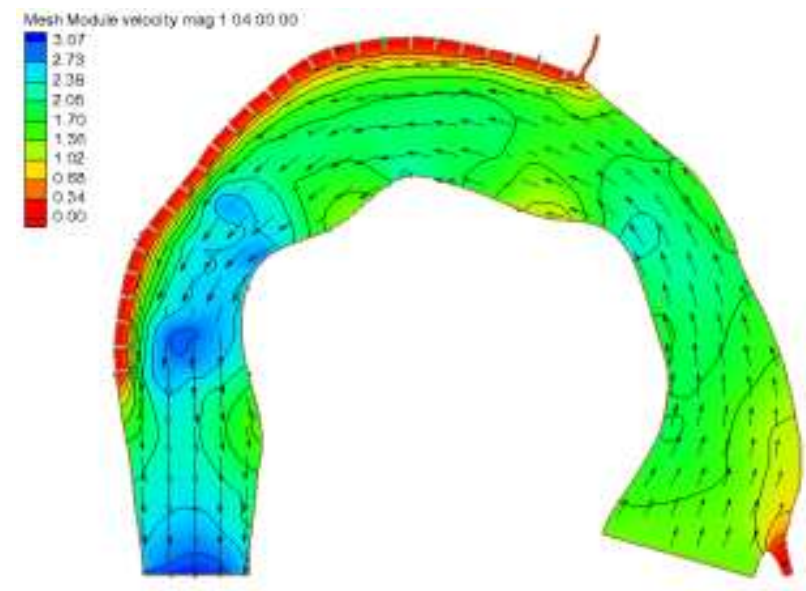

Figure 14. RMA Simulation Results $\left(\mathrm{Q}_{20}\right)$ Scenario 5

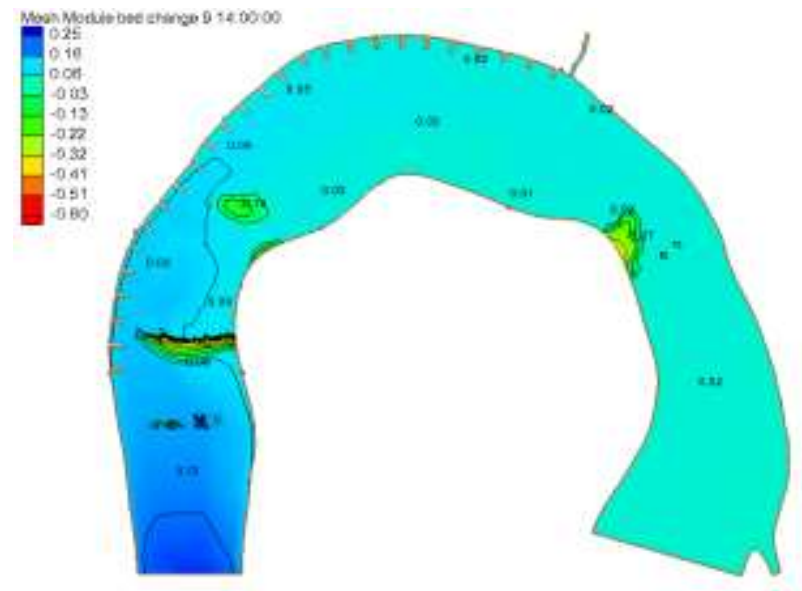

Figure 15. SED2D Simulation Results $\left(\mathrm{Q}_{20}\right)$ Scenario 5

\section{f. Scenario Modelling 5}

- Model Simulation RMA2

The 5-step scenario modelling is the same as the modelling scenario 1 (existing), however, in this scenario five, 26 groynes placed on the outer bend of the river, with the dimensions of the groyne: length of $17.5 \mathrm{~m}$; groyne perpendicular to flow; distance between groyne $35.5 \mathrm{~m}$.

Figure 14 shows that the arrows are the direction of the flow and the colour gradations consisting of red, yellow, green, and blue. The red colour represents the current velocity value of $0.0 \mathrm{~m} / \mathrm{sec}$. The yellow colour represents the current velocity value of $1.02 \mathrm{~m} / \mathrm{sec}$. The green colour represents the current velocity value of $2.05 \mathrm{~m} / \mathrm{sec}$, and the blue colour represents the current velocity value of $3.07 \mathrm{~m} / \mathrm{sec}$. The red colour dominates the river's outer side (right bank), yellow to blue colours dominate the inside of the river (left bank) and the river's middle.

Placing the groyne building on the outer side of the river (right bank) can reduce the river flow velocity to a low. Furthermore, the low flow velocity allows sedimentation to occur on the outer side of the river (right bank), so that the process of placing the groove as a river flow direction building can function following that was planned.

\section{- Model Simulation SED2D}

The SED2D model simulation aims to determine the distribution of sediment and river bed shear stress by adding 26 groyne, with the groyne's dimensions: length of $17.5 \mathrm{~m}$; groyne perpendicular to flow; distance between groyne $35.5 \mathrm{~m}$; due to the influence of $\mathrm{Q}_{20}$.

From Figure 15, it can be seen that blue colours dominate the colour gradation. In the condition of scenario 5, it is seen that there is a change in the river bed due to the $\mathrm{Q}_{20}$ flood discharge of $0.06 \mathrm{~m}$ to $0.16 \mathrm{~m}$, which is spread evenly on the left, centre and right of the river.

Figure 16 shows that the minimum river bed shear stress occurs on the river's right bank (outer river bend) and the maximum river bed shear stress occurs on the left bank of the river (inner river bend). Low riverbed shear stress values allow sedimentation, while high riverbed shear stress values allow erosion, so that in this condition there is a sedimentation process on the right bank of the river (outer river bend) and an erosion process occurs on the left bank of the river (bend in the river).

\section{g. Scenario Modelling 6}

- Model Simulation RMA2

The 6-step scenario modelling the same as the modelling in scenario 5, it only changes the direction of the curb inclined towards the upstream direction of the flow by $10^{\circ}$ (Figure 17). 

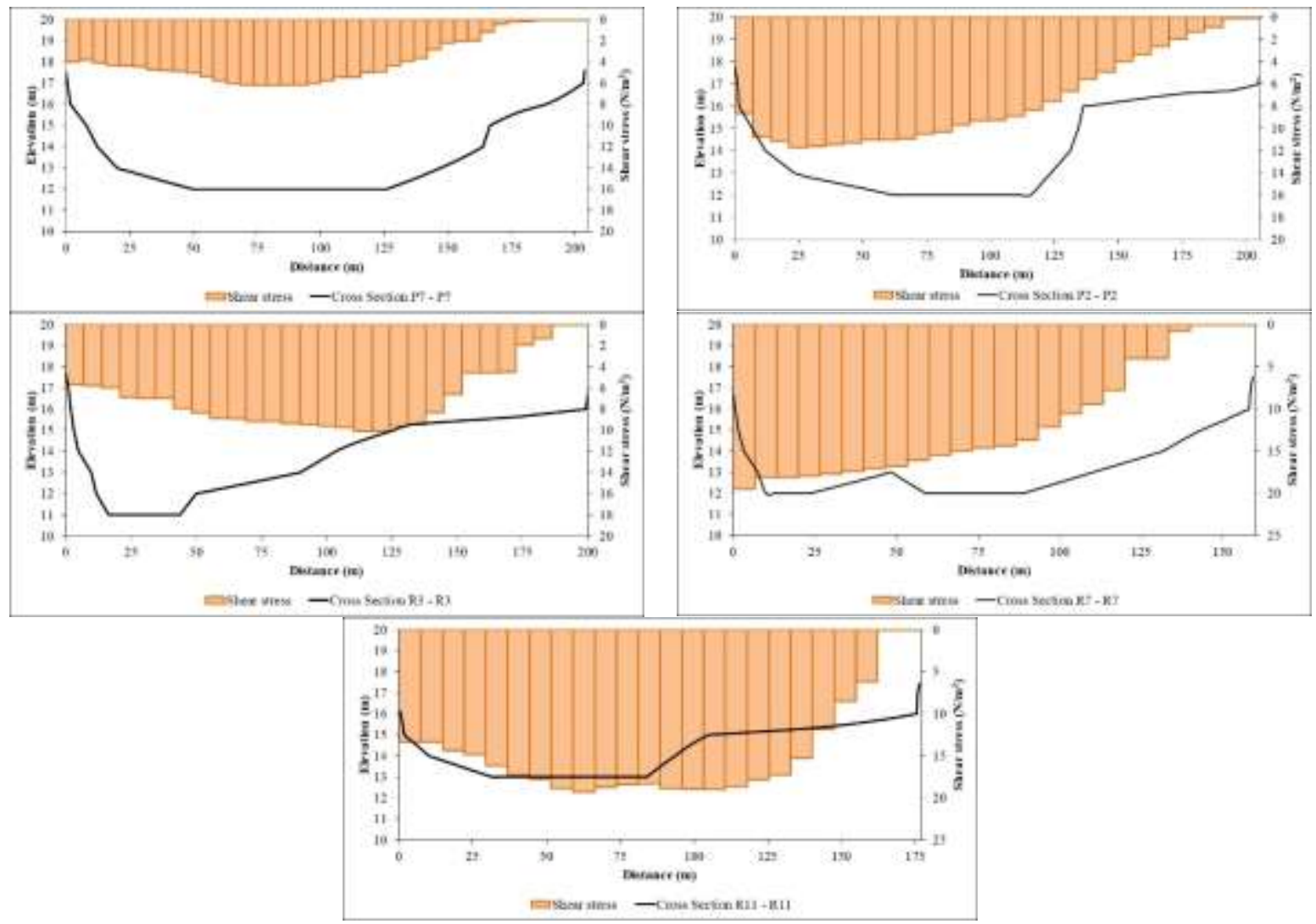

Figure 16. Distribution of Shear Stress (T) Riverbed Scenario $5\left(\mathrm{Q}_{20}\right)$

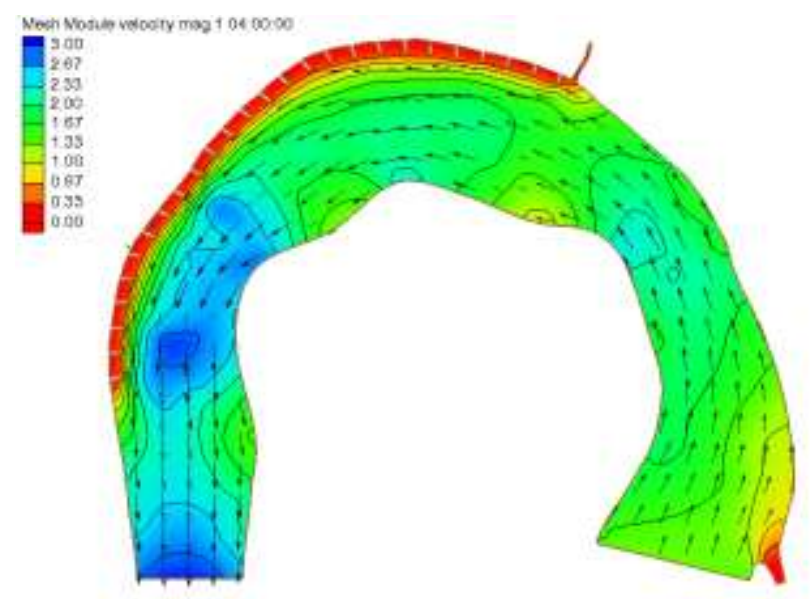

Figure 17. RMA Simulation Results $\left(\mathrm{Q}_{20}\right)$ Scenario 6

Figure 17 shows that the arrows are the direction of the flow and the colour gradations consisting of red, yellow, green, and blue. The red colour represents the current velocity value of $0.0 \mathrm{~m} / \mathrm{sec}$. The yellow colour represents the current velocity value of $1.00 \mathrm{~m} / \mathrm{sec}$. The green colour represents the current velocity value of $2.00 \mathrm{~m} / \mathrm{sec}$, and the blue colour represents the current velocity value of $3.00 \mathrm{~m} / \mathrm{sec}$. The red colour dominates the river's outer side (right bank), yellow to blue colours dominate the inside of the river (left bank) and the middle of the river.

Placing the groyne building on the outer side of the river (right bank) can reduce the river flow velocity to a low. Furthermore, where the low flow velocity allows sedimentation to occur on the outer 
side of the river (right bank) so that the process of placing the groove as a river flow direction building can function by that was planned.

- Model Simulation SED2D

The SED2D model simulation aims to determine the distribution of sediment and river bed shear stress by adding 26 groyne, with the dimensions of the groyne: length of $17.5 \mathrm{~m}$; groyne inclined $10^{\circ}$ to upstream; distance between groyne $35.5 \mathrm{~m}$; due to the influence of $\mathrm{Q}_{20}$.

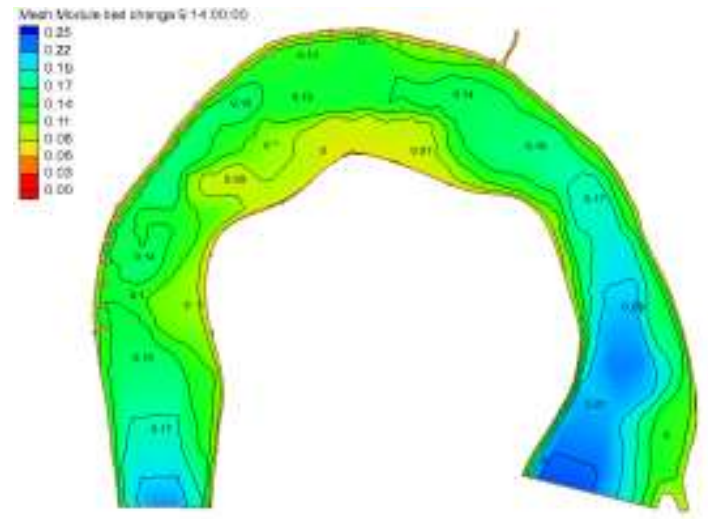

Figure 18. SED2D Simulation Results $\left(\mathrm{Q}_{20}\right)$ Scenario 6

From Figure 18, it can be seen that green and blue colours dominate the colour gradation. In the condition of scenario 6, it is seen that there is a change in the river bed due to the $\mathrm{Q}_{20}$ flood discharge of $0.06 \mathrm{~m}$ to $0.22 \mathrm{~m}$, which is spread evenly on the left, centre and right of the river.
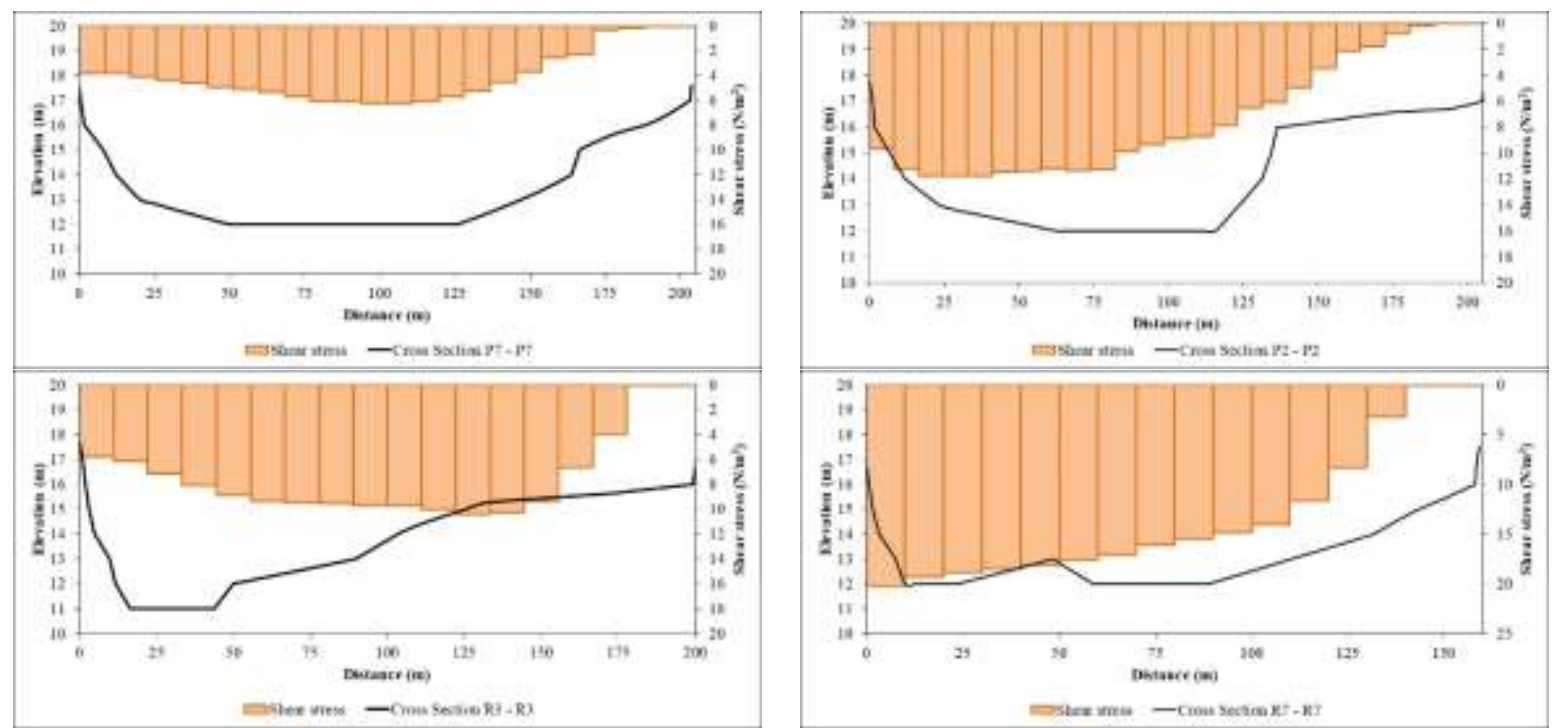

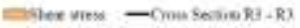
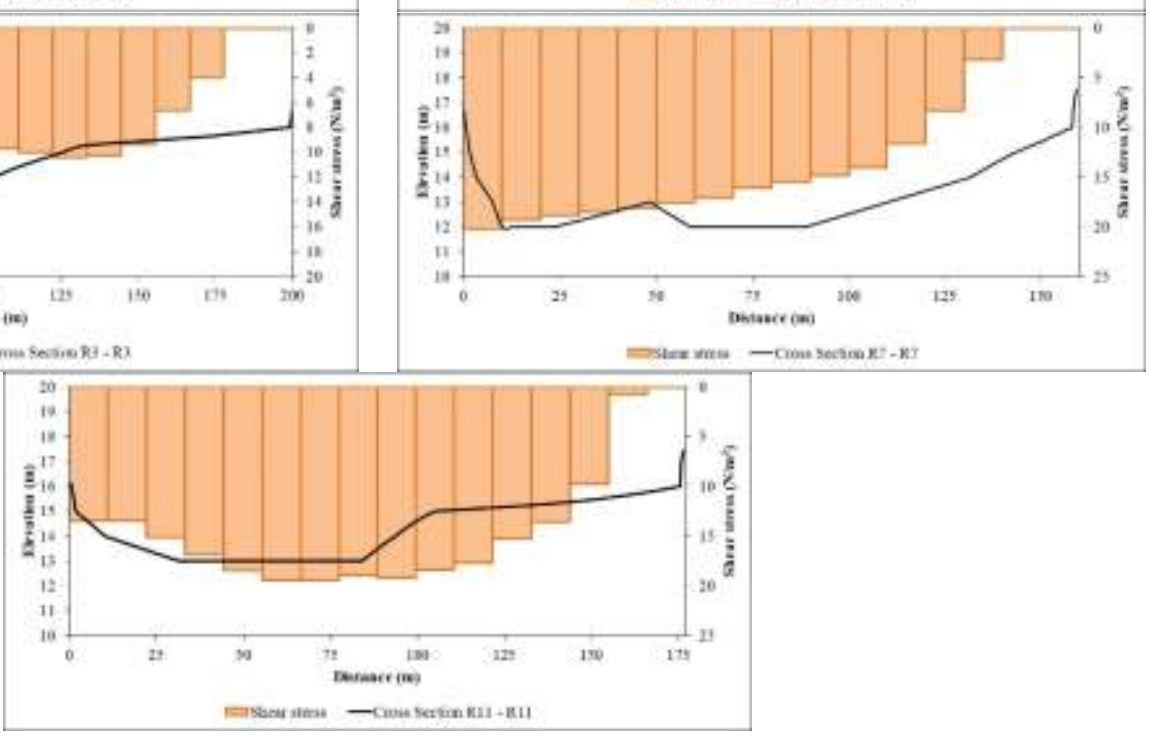

Figure 19. Distribution of Shear Stress (T) Riverbed Scenario $6\left(\mathrm{Q}_{20}\right)$ 
Figure 19 shows that the minimum river bed shear stress occurs on the river's right bank (outer river bend), and the maximum river bed shear stress occurs on the left bank of the river (inner river bend). Low riverbed shear stress values allow sedimentation, while high riverbed shear stress values allow erosion. in this condition there is a sedimentation process on the right bank of the river (outer river bend) and an erosion process occurs on the left bank of the river (bend in the river).

\section{h. Scenario Modelling 7}

- Model Simulation RMA2

The 7-step scenario modelling the same as the modelling in scenario 5, it only changes the direction of the curb inclined towards the downstream direction of the flow by $10^{\circ}$ (Figure 20).

From Figure 20, it can be seen that the arrows are the direction of the flow and the colour gradations consisting of red, yellow, green, and blue. The red colour represents the current velocity value of 0.0 $\mathrm{m} / \mathrm{sec}$, the yellow colour represents the current velocity value $1.02 \mathrm{~m} / \mathrm{sec}$, the green colour represents the current velocity value $2.04 \mathrm{~m} / \mathrm{sec}$, and the blue colour represents the current velocity value of 3.06 $\mathrm{m} / \mathrm{sec}$. The red colour dominates the outer side of the river (right bank), yellow to blue colours dominate the inside of the river (left bank) and the middle of the river.

By placing the groyne building on the outer side of the river (right bank) can reduce the river flow velocity to a low, where the low flow velocity allows sedimentation to occur on the outer side of the river (right bank), so that the process of placing the groove as a river flow direction building can function in accordance with that was planned.

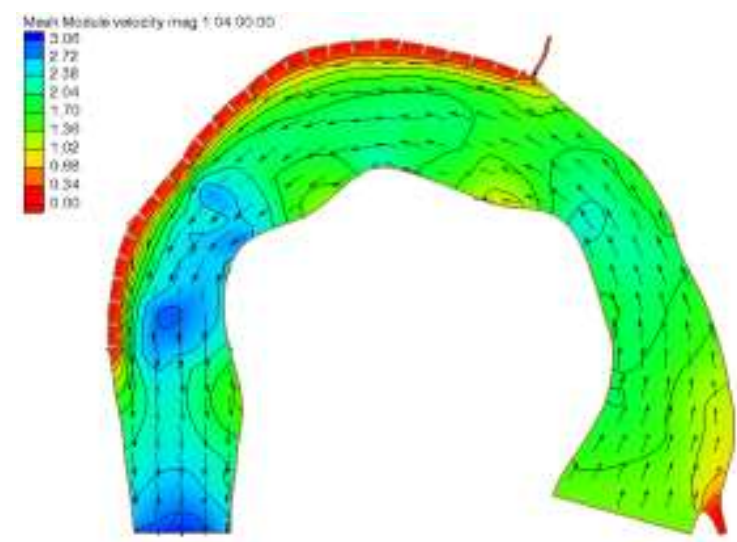

Figure 20. RMA Simulation Results $\left(\mathrm{Q}_{20}\right)$ Scenario 7

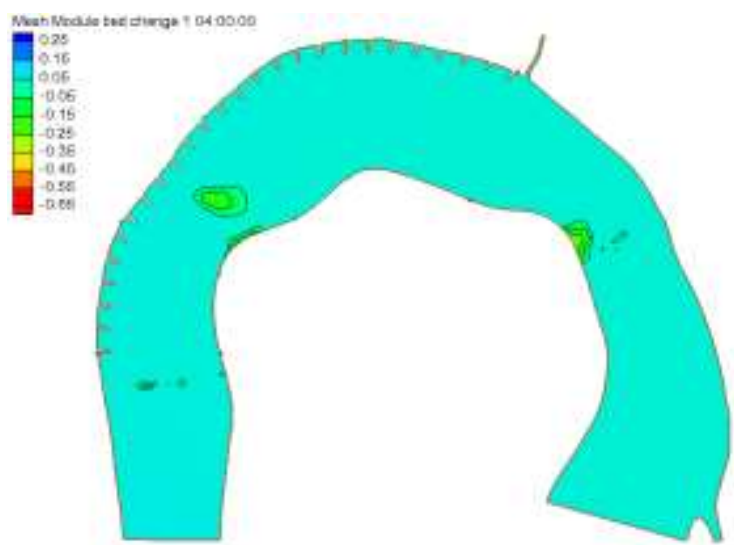

Figure 21. SED2D Simulation Results $\left(\mathrm{Q}_{20}\right)$ Scenario 7

- Model Simulation SED2D

The SED2D model simulation aims to determine the distribution of sediment and river bed shear stress by adding 26 groyne, with the dimensions of the groyne: length of $17.5 \mathrm{~m}$; groyne inclined $10^{\circ}$ to downstream; distance between groyne $35.5 \mathrm{~m}$; due to the influence of $\mathrm{Q}_{20}$.

From Figure 21, it can be seen that blue colours dominate the colour gradation. In scenario 4, there is a change in the river bed due to the Q20 flood discharge of $0.05 \mathrm{~m}$ to $0.18 \mathrm{~m}$, spread evenly on the left, centre, and right of the river.

Figure 22 shows that the minimum river bed shear stress occurs on the river's right bank (outer river bend) and the maximum river bed shear stress occurs on the left bank of the river (inner river bend). Low riverbed shear stress values allow sedimentation, meanwhile high riverbed shear stress values allow erosion. In this condition, there is a sedimentation process on the river's right bank (outer river bend) and an erosion process occurs on the left bank of the river (bend in the river). 

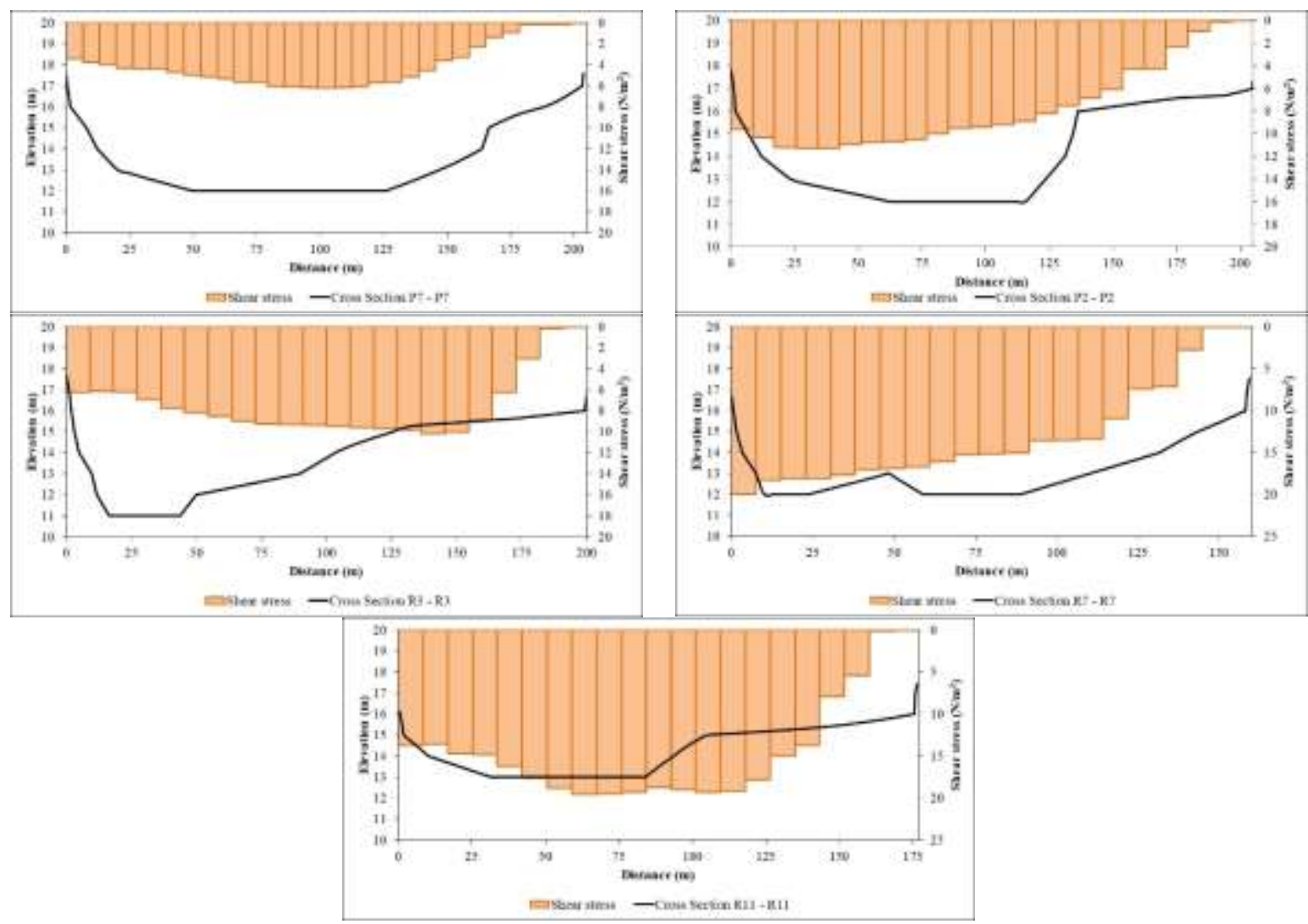

Figure 22. Distribution of Shear Stress (T) Riverbed Scenario $7\left(\mathrm{Q}_{20}\right)$

\section{i. Comparison of Simulation Results}

Based on the simulations that have been carried out, the results are obtained in the form of velocity distribution, river bed shear stress, and sediment distribution due to the influence of groyne placement on the outer bend of the river. A comparative analysis of the groyne placement will be carried out from the simulation, which is more useful to reduce scouring on river banks.

Table 4. Recapitulation of Velocity Distribution

\begin{tabular}{cccccccc}
\hline \multirow{2}{*}{ Cross Section } & \multicolumn{7}{c}{ Velocity right bank (m/sec) } \\
\cline { 2 - 8 } & Scenario 1 & Scenario 2 & Scenario 3 & Scenario 4 & Scenario 5 & Scenario 6 & Scenario 7 \\
\hline P7 & 1.020 & 0.027 & 0.006 & 0.053 & 0.030 & 0.024 & 0.077 \\
\hline P2 & 1.391 & 0.012 & 0.033 & 0.027 & 0.141 & 0.026 & 0.110 \\
\hline R3 & 1.080 & 0.030 & 0.047 & 0.041 & 0.015 & 0.036 & 0.031 \\
\hline R7 & 1.822 & 0.035 & 0.109 & 0.115 & 0.041 & 0.028 & 0.035 \\
\hline R11 & 1.610 & 0.038 & 0.010 & 0.103 & 0.033 & 0.067 & 0.029 \\
\hline Average & $\mathbf{1 . 3 8 5}$ & $\mathbf{0 . 0 2 8}$ & $\mathbf{0 . 0 4 1}$ & $\mathbf{0 . 0 6 8}$ & $\mathbf{0 . 0 5 2}$ & $\mathbf{0 . 0 3 6}$ & $\mathbf{0 . 0 5 6}$ \\
\hline
\end{tabular}

\begin{tabular}{cccccccc}
\hline \multirow{2}{*}{ Cross Section } & \multicolumn{7}{c}{ Velocity left bank (m/sec) } \\
\cline { 2 - 8 } P7 & Scenario 1 & Scenario 2 & Scenario 3 & Scenario 4 & Scenario 5 & Scenario 6 & Scenario 7 \\
\hline P2 & 0.810 & 1.096 & 1.111 & 1.082 & 1.095 & 1.074 & 1.020 \\
\hline R3 & 1.267 & 1.719 & 1.672 & 1.661 & 1.602 & 1.689 & 1.685 \\
\hline R7 & 1.536 & 1.561 & 1.293 & 1.314 & 1.287 & 1.293 & 1.354 \\
\hline R11 & 2.323 & 2.335 & 2.348 & 2.320 & 2.359 & 2.351 \\
\hline Average & 1.019 & 1.890 & 1.888 & 1.888 & 1.891 & 1.893 & 1.919 \\
\hline
\end{tabular}


Form Table 4, by adding the curly structure on the outer bend of the river or the right bank of the river (scenario 2 - scenario 7), the current velocity on the right bank of the river has decreased significantly with an average value of the flow velocity of the right bank of the river is $0.047 \mathrm{~m} / \mathrm{sec}$. With the average value of the current velocity on the river's right bank, which is smaller than the grain sediment's velocity, the deposition process will occur on the right bank. Whereas on the river's left bank, with the average value of the flow velocity of the river's left bank is greater than the velocity of grain sediment, then the scouring process will occur on the left bank of the river.

Form table 5, by adding the curly structure on the outer bend of the river or the right bank of the river (scenario 2-scenario 7), the value of the riverbed shear stress on the right bank of the river has decreased significantly with an average value of the riverbed shear stress on the right bank of the river of 0.012 $\mathrm{N} / \mathrm{m}^{2}$. With a small riverbed shear stress value, it can be said that grain movement has not occurred. While on the river's left bank, the average value of the riverbed shear stress on the left bank of the river is $10.554 \mathrm{~N} / \mathrm{m}^{2}$, so it can be said that there will be movement in the grain or called sediment transport.

From the analysis of current velocity distribution and river bed shear stress distribution, it can be stated that the flow velocity and river bed shear stress have an equivalent relationship in influencing the river geometry because these two parameters can cause the river to experience scouring and deposition.

By placing the groyne on the outer bend of the river, it can reduce the current velocity and the shear stress of the river bed at the outer bend of the river, where the reduced value of the current velocity and the riverbed shear stress on the outer bend of the river can cause a sedimentation process or sedimentation process in the outer bend of the river walk naturally.

Tabel 5. Recapitulation of Shear Stress

\begin{tabular}{|c|c|c|c|c|c|c|c|}
\hline \multirow{2}{*}{ Cross Section } & \multicolumn{7}{|c|}{ Riverbed shear stress right bank $\left(\mathrm{N} / \mathrm{m}^{2}\right)$} \\
\hline & Scenario 1 & Scenario 2 & Scenario 3 & Scenario 4 & Scenario 5 & Scenario 6 & Scenario 7 \\
\hline P7 & 3.567 & 0.003 & 0.000 & 0.009 & 0.003 & 0.002 & 0.021 \\
\hline $\mathrm{P} 2$ & 6.794 & 0.001 & 0.004 & 0.003 & 0.061 & 0.002 & 0.035 \\
\hline R3 & 4.126 & 0.003 & 0.008 & 0.059 & 0.001 & 0.006 & 0.003 \\
\hline R7 & 12.144 & 0.004 & 0.040 & 0.012 & 0.006 & 0.004 & 0.006 \\
\hline R11 & 9.695 & 0.006 & 0.000 & 0.037 & 0.004 & 0.018 & 0.003 \\
\hline Average & 7.265 & 0.003 & 0.011 & 0.024 & 0.015 & 0.006 & 0.014 \\
\hline \multirow{2}{*}{ Cross Section } & \multicolumn{7}{|c|}{ Riverbed shear stress left bank $\left(\mathrm{N} / \mathrm{m}^{2}\right)$} \\
\hline & Scenario 1 & Scenario 2 & Scenario 3 & Scenario 4 & Scenario 5 & Scenario 6 & Scenario 7 \\
\hline P7 & 2.253 & 3.993 & 4.097 & 3.882 & 3.992 & 3.831 & 3.450 \\
\hline $\mathrm{P} 2$ & 5.666 & 10.045 & 9.467 & 9.418 & 8.693 & 9.687 & 9.630 \\
\hline R3 & 8.178 & 7.628 & 5.755 & 5.899 & 5.713 & 5.763 & 6.288 \\
\hline R7 & 8.075 & 19.508 & 19.679 & 19.964 & 19.494 & 20.162 & 19.987 \\
\hline R11 & 13.868 & 13.421 & 13.331 & 13.270 & 13.358 & 13.438 & 13.770 \\
\hline Average & 7.608 & 10.919 & 10.466 & 10.487 & 10.250 & 10.576 & 10.625 \\
\hline
\end{tabular}

Table 6. Recapitulation of Riverbed Changes

\begin{tabular}{cccccccc}
\hline \multirow{2}{*}{ Cross Section } & \multicolumn{7}{c}{ Riverbed changes Maximum (m) } \\
\cline { 2 - 8 } & Scenario 1 & Scenario 2 & Scenario 3 & Scenario 4 & Scenario 5 & Scenario 6 & Scenario 7 \\
\hline P7 & 0.031 & 0.138 & 0.213 & 0.146 & 0.029 & 0.147 & 0.028 \\
\hline P2 & 0.041 & 0.122 & 0.205 & 0.134 & 0.039 & 0.136 & 0.038 \\
\hline R3 & 0.059 & 0.118 & 0.242 & 0.147 & 0.057 & 0.150 & 0.057 \\
\hline R7 & 0.076 & 0.105 & 0.229 & 0.141 & 0.074 & 0.144 & 0.078 \\
\hline R11 & 0.095 & 0.104 & 0.205 & 0.141 & 0.095 & 0.144 & 0.099 \\
\hline Total & 0.301 & 0.588 & 1.094 & 0.709 & 0.294 & 0.721 & 0.301 \\
\hline
\end{tabular}


From Table 6, it is found that the maximum river bed change occurs in scenario 3 of $1.094 \mathrm{~m}$. It means that from the simulation results of the SED2D model, the height of riverbed sediment deposits on the right bank of the river for 230 hours is $1.094 \mathrm{~m}$.

\section{Conclusions}

One of the groyne's primary purposes is to reduce the river flow's speed along the riverbank, accelerate sedimentation, and ensure embankments/cliffs' safety against scouring. From the simulation results of the model on the Lariang River by adding the groyne building on the outer bend of the river, it was found that for the simulation model scenario 2 to scenario 7 , a reduction in current velocity and a decrease in river bed shear stress occurred along the river bank. From the model simulation results by adding a groyne building on the river's outer bend for the simulation model scenario 2 to scenario 7 , the largest sedimentation production is in scenario 3, namely the height of riverbed sediment deposits 230 hours of $1,094 \mathrm{~m}$. Furthermore, the grout building's effective placement is determined based on a maximum change in the riverbed scenario. In this case scenario 3 , wherein the groyne's placement and dimensions are the length of $17.5 \mathrm{~m}$; distance between groyne $24.4 \mathrm{~m}$; the groyne is inclined upstream in the direction of flow $10^{\circ}$.

\section{References}

[1] Ackers, P., and W. R. White (1973): Sediment transport: New approach and analysis, Corrections (1993).

[2] Asdak, C. 1995. Hidrologi dan Pengelolaan Daerah Aliran Sungai, Yogyakarta: Gadjah Mada University Press.

[3] Chow, Ven Te, (1997), Hidrolika Saluran Terbuka (Open Channel Hydraulics), Erlangga, Bandung.

[4] Donnell, Barbara P., Letter, Joseph V., McAnally, W. H., and others, "Users Guide for RMA2 Version 4.5," [27 Sept] 2011, [http://chl.wes.army.mil/software/tabs/docs.htp].

[5] Iskandar, 2016. Analisa Pengaruh Penempatan Krib Terhadap Distribusi Sedimen di Pertemuan Sungai garang dan Kreo. Jurnal Teknik Pengairan. E-ISSN: 2477-6068, P-ISSN: 2086-1761

[6] James Zulfan, Yiniarti Eka Kumala, 2018. Efektivitas Krib Untuk Mengurangi Gerusan di Tikungan Luar Sungai Bengawan Solo. Jurnal Teknik Hidraulik, Vol. 9 No. 2, Desember 2018: $115-126$

[7] Letter, Joseph V., Teeter, Teeter, Allen M., Donnell, Barbara P., and others, "User's Guide for SED2D Version 4.5 [20 Jan] 2006, [http://chl.wes.army.mil/software/tabs/doc.htp]

[8] Soemarto, CD. 1987. Hidrologi Teknik. Surabaya: Penerbit Usaha Nasional.

[9] Soewarno. 1991. Hidrologi, Pengukuran Dan Pengolahan Data Aliran Sungai (Hidrometri). Bandung: Penerbit Nova.

[10] Sosrodarsono, Suyono dan Masateru Tominaga, K. 1994. Perbaikan dan Pengaturan Sungai. Jakarta: PT. Pradnya Paramita.

[11] Suharjoko, 2008. Methode Aplikasi Bangunan Krib Sebagai Pelindung terhadap Bahaya Erosi Tebing Sungai. Jurnal Aplikasi ISSN. 1907-753X

[12] Haribowo, R., Dermawan, V., \& Yudha, N. (2018). Application of Artificial Neural Network For Defining The Water Quality in The River. Civil and Environmental Science Journal (Civense), 1(1), pp.12-18. doi:https://doi.org/10.21776/ub.civense.2018.00101.2.

[13] Juwono, P., Asmaranto, R., \& Murdhianti, A. (2020). Stability of existing Banyukuwung DAM in recent hydrology and geotechnical conditions. Civil and Environmental Science Journal (Civense), 3(2), 60-71. doi:https://doi.org/10.21776/ub.civense.2020.00302.1. 